\title{
Gas-Phase Peptide Sulfinyl Radical lons: Formation and Unimolecular Dissociation
}

\author{
Lei Tan, Yu Xia
}

Department of Chemistry, Purdue University, West Lafayette, IN 47907-2084, USA

\begin{abstract}
A variety of peptide sulfinyl radical (RSO•) ions with a well-defined radical site at the cysteine side chain were formed at atmospheric pressure (AP), sampled into a mass spectrometer, and investigated via collision-induced dissociation (CID). The radical ion formation was based on AP reactions between oxidative radicals and peptide ions containing single inter-chain disulfide bond or free thiol group generated from nanoelectrospray ionization (nanoESI). The radical induced reactions allowed large flexibility in forming peptide radical ions independent of ion polarity (protonated or deprotonated) or charge state (singly or multiply charged). More than 20 peptide sulfinyl radical ions in either positive or negative ion mode were subjected to low energy collisional activation on a triple-quadrupole/linear ion trap mass spectrometer. The competition between radical- and charge-directed fragmentation pathways was largely affected by the presence of mobile protons. For peptide sulfinyl radical ions with reduced proton mobility (i.e., singly protonated, containing basic amino acid residues), loss of $62 \mathrm{Da}\left(\mathrm{CH}_{2} \mathrm{SO}\right)$, a radicalinitiated dissociation channel, was dominant. For systems with mobile protons, this channel was suppressed, while charge-directed amide bond cleavages were preferred. The polarity of charge was found to significantly alter the radical-initiated dissociation channels, which might be related to the difference in stability of the product ions in different ion charge polarities.
\end{abstract}

Key words: Peptide radical ion, Sulfinyl radical, Disulfide bond, Collision-induced dissociation, Tandem mass spectrometry

\section{Introduction}

$\mathrm{P}$ rotein radicals, although typically existing as transient species, carry out important roles in biological systems [1]. Several classes of enzymes utilize radicals as active sites to control their catalytic functions [2-5]. In addition, protein radicals are often produced as intermediates during oxidative damage of proteins induced by reactive oxygen species [69]. Investigating the chemical properties of protein radicals is highly desirable in order to understand the associated biological events. Mass spectrometry (MS) has been utilized

Electronic supplementary material The online version of this article (doi:10.1007/s13361-012-0465-0) contains supplementary material, which is available to authorized users.

Correspondence to: Yu Xia; e-mail: yxia@purdue.edu

Published online: 22 August 2012 to analyze the stable reaction products of biomolecules after exposure to radical attack in solution [10-12]. The distonic ion approach pioneered by Kenttämaa and co-workers allows exploration of radical attack on biomolecules via gas-phase ion/molecule reactions [13]. In those studies, distonic ions (ions with separated charge and radical site) were used as surrogates of radicals to react with neutral amino acids or dipeptides, and several classes of reaction channels were identified $[14,15]$. Another MS approach is to directly form and study peptide/protein radical ions in the gas-phase. Although electron ionization (EI) has been widely used to produce radical cations of small organic compounds [16], it is difficult to be applied to biomolecules, which have low vapor pressure and easily decompose upon heating. Developing versatile approaches of generating gasphase biomolecule radical ions remains an active research area. Electron transfer or electron capture processes give rise 
to hydrogen rich radical cations, in which the peptide contains more hydrogen(s) than the corresponding even electron species [17-20]. Dissociation of the hydrogen rich radical cations often gives rise to $c$ and $z \bullet$ ions, along with side-chain losses, through which they can convert quickly to hydrogen deficient radical ions [19-21]. Hydrogen deficient cations can be generated by a variety of methods: laser ablation followed by ultraviolet (UV) photoionization [22, 23]; collision-induced dissociation (CID) of metal-ligand-peptide complexes [24-26]; CID of peptide derivatives with labile bonds such as S-nitrosylation [27, 28], serine/homoserine nitrate esters [29], peroxycarbamates [30], 2,2,6,6-tetramethylpiperidine-1-oxy (TEMPO) [31, 32], and 4,4'-azobis(4-cyanopentanoic acid) (Vazo 68) [33]; UV photolysis of iodinated tyrosine containing peptides [34]; or noncovalent complexes with photolabile precursor [35]; electroninduced dissociation of multiply charged ions [36, 37]. Hydrogen deficient radical anions can be formed by electron detachment [38] or photodetachment [39] from multiply deprotonated molecules, CID of peptide-metal complexes [40, 41], and photodissociation of iodinated peptide [42].

By introducing a radical site to a peptide ion, the gas-phase ion chemistry can be drastically altered from the even-electron counterpart. Several groups have utilized both experimental approaches (i.e., ion/molecule reactions $[14,15,27]$ and ion spectroscopy [43-45]) and theoretical calculations [21, 46-49] to investigate the structures of amino acid or small peptide radical ions. Radical ion chemistry, such as intramolecular radical migration $[27,50]$ and competition between charge- and radical-directed dissociation upon collisional activation [49-51] have also been explored with different chemical systems. The capability of controlling the radical site upon its formation is highly desirable in studying the fundamental aspects as mentioned above.

Small organic sulfinyl radicals, such as $\mathrm{HSO} \bullet$ and $\mathrm{CH}_{3} \mathrm{SO} \bullet$, are important products for oxidation of pollutants like $\mathrm{H}_{2} \mathrm{~S}$ and $\mathrm{CH}_{3} \mathrm{SH}$, as well as photolysis of sulfoxide, and thus play an important role in the atmospheric sulfur cycles [52-54]. Protein sulfinyl radicals have been detected by electron spin resonance spectroscopy for glycyl-radical enzyme system upon its exposure to molecular oxygen $[55,56]$. It was suggested that the sulfinyl radical species might participate in adjusting the glycyl/ thiyl radical equilibrium and reactivity of radical enzyme [55, 57]. Due to the transient nature of radical species in solution, very little has been explored on the chemical property of protein or peptide sulfinyl radicals. In previous studies, we observed that disulfide bonds within peptides could be cleaved when the peptide nanoelectrospray plume was allowed to interact with the after-glow of a helium plasma in air, resulting in the formation of sulfinyl radical $(-\mathrm{SO} \bullet)$ and sulfhydryl $(-\mathrm{SH})$ at the cleavage site $[58,59]$. Atmospheric pressure (AP) reactions induced by reactive radicals were suggested to be responsible for the oxidative cleavage of the disulfide bond. The radical induced reactions allowed the formation of a series of peptide radical ions (noted as $[\mathrm{M}+\mathrm{nH}+\mathrm{OH}]^{\mathrm{n} \cdot+}$ ) containing sulfinyl radical when using intra-chain disulfide linked peptides. However, the location of the radical site was ambiguous given that the sulfinyl radical could be formed at either cysteine residue. In this study, AP reactions between oxidative radicals and peptides containing single inter-chain disulfide bonds or free cysteine residues were developed to form peptide sulfinyl radical cations or anions with known radical location. With this capability, the gas-phase unimolecular dissociation of more than 20 peptide sulfinyl radical ions was investigated via CID. In this study, we intend to shed light on how peptide sequence, charge states, and charge polarity would affect the fragmentation behavior of peptide sulfinyl radical ions, and gain insight into the competition between charge- and radical-directed dissociation in peptide radical ions.

\section{Experimental}

\section{Materials}

Peptides used in this study are listed in Tables 1 and 2. Most peptides with single inter-chain disulfide bonds were produced either from enzymatic digestion of peptides with an intra-chain disulfide bond or from oxidation of single cysteine containing peptide to form the disulfide linked dimer. Peptides CLPTRHMAC (disulfide bond: 1-9), CGNKRTRGC (disulfide bond: 1-9), CSRNLIDC (disulfide bond: 1-8), CNGRC$\mathrm{NH}_{2}$ (disulfide bond: 1-5), CIELLQARC (disulfide bond: 19), CYAAPLKPAKSC (disulfide bond: 1-12), and AGCKNFFWKTFTSC (disulfide bond: 3-14) were purchased from Anaspec (San Jose, CA, USA). These peptides were subjected to trypsin digestion with an enzyme/substrate ratio of 1:50, and incubated at $37^{\circ} \mathrm{C}$ in $50 \mathrm{mM}$ ammonium bicarbonate buffer for $2 \mathrm{~h}$. The tryptic digestion of these peptides gave rise to peptides 1-7 as listed in Table 1, respectively. Peptide 8 was formed from pepsin digestion of peptide CTTHWGFTLC (disulfide bond 1-10, Anaspec). The pepsin digestion was performed in $5 \%$ formic acid with an enzyme/substrate ratio of $1: 50$ at $37^{\circ} \mathrm{C}$ for $4 \mathrm{~h}$. Peptide 9 was

Table 1. List of Inter-Chain Disulfide Peptides for the Formation of Peptide Sulfinyl Radical Ions. Each Chain within the Peptide was Denoted with "A" or "B"

\begin{tabular}{|c|c|c|c|c|}
\hline Label & & Sequence & Label & Sequence \\
\hline 1 & & $\begin{aligned} & \text { CLPTR } \\
\text { HMAC } & \text { I }\end{aligned}$ & 6 & $\begin{array}{l}\text { A } \text { CYAPPLKPAK } \\
\text { B SC }\end{array}$ \\
\hline 2 & $\begin{array}{l}\text { A } \\
\text { B }\end{array}$ & $\begin{array}{l}\text { CGNKR } \\
\text { I } \\
\text { GC }\end{array}$ & 7 & $\begin{array}{lc}\text { A } & \text { AGCK } \\
\text { B } & \text { TFTSC }\end{array}$ \\
\hline 3 & & $\begin{array}{r}\text { CSR } \\
\text { NLIDC }\end{array}$ & 8 & $\begin{array}{l}\text { A } \quad \text { CTTHWGF } \\
\text { B } 1 \text { TLC }\end{array}$ \\
\hline 4 & $\begin{array}{l}\text { A } \\
\text { B }\end{array}$ & $\begin{array}{l}\mathrm{CNGR} \\
1 \\
\mathrm{C}-\mathrm{NH}_{2}\end{array}$ & 9 & $\begin{array}{ll}\text { A } & \text { CGAILR } \\
\text { B } & \text { I } \\
& \text { CGAILR }\end{array}$ \\
\hline 5 & $\begin{array}{l}\text { A } \\
\text { B }\end{array}$ & $\begin{array}{l}\text { CIELLQAR } \\
\text { I }\end{array}$ & 10 & $\begin{array}{ll}\text { A } & \gamma \mathrm{ECG} \\
\mathrm{B} & \gamma \mathrm{ECG}\end{array}$ \\
\hline
\end{tabular}


Table 2. List of Peptides Containing Free Cysteine Residues for the Formation of Peptide Sulfinyl Radical Ions

\begin{tabular}{llcl}
\hline Label & Sequence & Label & Sequence \\
\hline $\mathbf{1 1}$ & CLPTR & $\mathbf{1 5}$ & RGGALC \\
$\mathbf{1 2}$ & CAR & $\mathbf{1 6}$ & RGCALG \\
$\mathbf{1 3}$ & RGDC & $\mathbf{1 7}$ & RVCIHPF \\
$\mathbf{1 4}$ & GCGK & $\mathbf{1 8}$ & CFRHDSGY \\
\hline
\end{tabular}

formed upon oxidation of peptide CGAILR (CPC Scientific, Sunnyvale, CA, USA) by adding $10 \mu \mathrm{L}$ of $1 \%$ hydrogen peroxide to $1 \mathrm{~mL}$ of $10 \mu \mathrm{M}$ peptide in $50 / 50$ $\mathrm{MeOH} / \mathrm{H}_{2} \mathrm{O}$ solution, and stirring for $5 \mathrm{~h}$. Peptide 10, oxidized glutathione, was bought from Sigma-Aldrich (St. Louis, MO). Peptide 11 was generated by reduction of disulfide bond in peptide CD 154 (CLPTRHMAC, 1-9 disulfide bond, Anaspec), followed by trypsin digestion. Reduction of disulfide bond was achieved by mixing $10 \mu \mathrm{L}$ peptide solution $(1 \mathrm{mg} / \mathrm{mL}$ in water $)$ with 10 times molar excess of $1 \mathrm{mg} / \mathrm{mL}$ dithiothreitol solution (DTT, Sigma-Aldrich). The $\mathrm{pH}$ of solution was adjusted to 8 by adding $1 \%$ ammonium hydroxide and the final mixture was allowed to react for $30 \mathrm{~min}$ at room temperature. Peptides 12 and 14 were synthesized by CPC Scientific. Peptide 13 and 18 were purchased from Anaspec. Peptides 15-17 were synthesized by SynBioSci (Livermore, CA, USA). Working solutions for nanoESI were prepared to a final concentration of $10 \mu \mathrm{M}$ of a peptide in 50/49/1 $\mathrm{MeOH} / \mathrm{H}_{2} \mathrm{O} / \mathrm{HOAc}$ (vol/vol/vol).

\section{Mass Spectrometry and AP Radical Reactions}

Most experiments were performed on a 4000 QTRAP mass spectrometer (Applied Biosystems, Toronto, Canada), with a hybrid triple quadrupole/linear ion trap configuration. Two types of collisional activation methods are available with this instrument, beam-type CID and ion trap CID. For beam-type $\mathrm{CID}$, parent ions are isolated by Q1 quadrupole and accelerated to Q2 for collisional activation. In ion trap CID, ion activation is conducted in the Q3 linear ion trap with a dipolar excitation. In this study, tandem mass spectrometric experiments were facilitated by ion trap CID unless specified. Mass analysis was performed in Q3 in linear ion trap mode. Typical parameters of the mass spectrometry used were set as follows: spray voltage, 1400-1800 V; curtain gas, $10 \mathrm{psi}$; declustering potential, $20 \mathrm{~V}$; scan rate, $1000 \mathrm{Da} / \mathrm{s}$. Data shown here were typical an average of more than 50 scans. In order to conduct AP ion/radical reactions, the nanoESI plume of peptide sample was allowed to interact with the after-glow region of an AP helium low temperature plasma (LTP) enabled in the side arm of a T-shaped glass tube placed in front of the entrance of mass spectrometer [58]. The schematics of the instrument and reaction setup are shown in Scheme S-1 of the supplemental material. Accurate mass measurements were performed on an LTQ-Orbitrap (Thermo Fisher Scientific, San Jose, CA, USA) with a mass resolution of 30,000 with an internal mass calibration.

\section{Results and Discussion}

\section{Nomenclature}

' $M$ ' was used to describe an even electron peptide species in its original state, with no addition or subtraction of protons. "A" and "B" were used to denote the different chains for inter-chain disulfide peptides based on homolytic cleavage of the disulfide bond (without any extra atom attached to the sulfur after cleavage). Superscripts, ${ }^{\mathrm{SH}}$ and ${ }^{\mathrm{SO} \cdot}$ to the left of "A" or "B" chain symbols indicated the formation of sulfhydryl $(-\mathrm{SH})$ and sulfinyl radical $(-\mathrm{SO} \bullet)$ at the cysteinyl sulfur, respectively. In cases where sequences of the peptides were written out, ${ }^{\mathrm{SO}^{\circ} \mathrm{C}}$ was used to emphasize the existence of sulfinyl radical within the peptide ions. For fragments derived from peptide sulfinyl ions, superscript, ${ }^{\mathrm{SO} \cdot}$ again was used to suggest the retention of sulfinyl radical for that fragment ion, e.g. ${ }^{\mathrm{SO}^{*}} b_{n}{ }^{+}$or ${ }^{S O} y_{n}{ }^{+}$.

\section{Formation of Peptide Sulfinyl Radical Ions \\ Radical Attack of Inter-Chain Disulfide Bond}

Studies have shown that molecular species $\left(\mathrm{OH}, \mathrm{N}_{2}, \mathrm{~N}_{2}{ }^{+}, \mathrm{NO}\right.$, and $\mathrm{NO}_{2}$ ) as well as atomic species (metastable $\mathrm{He}, \mathrm{H}$, and $\mathrm{O}$ ) are abundant in an AP helium LTP [60, 61]. For peptides having intra-chain disulfide bonds, one major product after the nanoESI plume interacting with LTP were ions corresponding to the addition of $\mathrm{O}$ and $\mathrm{H}$ to the intact peptide $([\mathrm{M}+\mathrm{nH}+\mathrm{OH}]$ $\left.{ }^{n \bullet+}\right)[58,59]$. Note that since many oxidative radicals or species coexisted in the helium LTP, the exact reaction mechanism for this phenomenon was unclear. One possible route of forming these products could come from the dissociative addition of hydroxyl radical from LTP to the disulfide bond, resulting in sulfinyl radical $(-\mathrm{SO} \bullet)$ and sulfhydryl $(-\mathrm{SH})$ at the cleavage site. However, the location of the radical site from the above system was ambiguous given that the sulfinyl radical could be formed at either cysteine residue. In this study, peptides with inter-chain disulfide bond were employed such that the two peptide chains were separated after radical reactions and peptide sulfinyl radical ions could be mass distinguished (Scheme 1).

A typical reaction spectrum of the inter-chain disulfide peptides in positive ionization mode is demonstrated with peptide 1 (Figure 1a). Peptide 1 has two chains (A and B) linked through a disulfide bond. The masses of the neutral $\mathrm{A}$ and $\mathrm{B}$ chains (derived from a homolytic cleavage of the disulfide bond) are indicated in the inset of Figure 1. Note that before applying the plasma, only intact peptide ions could be observed from nanoESI. When the LTP plasma and the nanoESI were both functioning, the formation of sulfhydryl $(-\mathrm{SH})$ and sulfinyl radical (-SO•) from each peptide chain, notated as $\left[{ }^{\mathrm{SH}} \mathrm{A}+\mathrm{H}\right]^{+},\left[{ }^{\mathrm{SH}} \mathrm{B}+\mathrm{H}\right]^{+},\left[{ }^{\mathrm{SO} \cdot} \mathrm{A}+\mathrm{H}\right]^{+}$, and $\left[{ }^{\mathrm{SO} \cdot} \mathrm{B}+\mathrm{H}\right]$ ${ }^{+}$, could be clearly identified. Other minor reaction products were also observed, such as $-1 \mathrm{Da}$ or $-2 \mathrm{Da}$ to the intact peptide ions and separated chains, and consecutive oxidation on amino acid side chains corresponding to $\mathrm{n} \times 16$ Da mass increases $[58,59]$. Compared with peptide radical cations, 


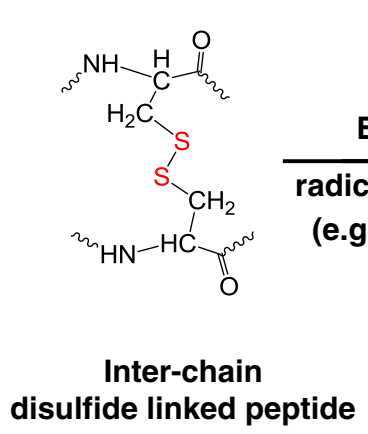

disulfide linked peptide

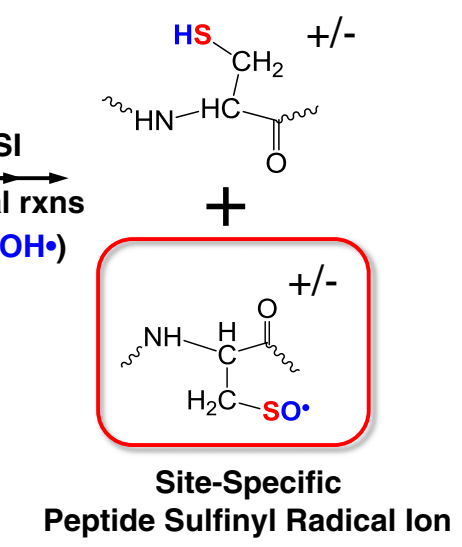

Scheme 1. Formation of site-specific peptide sulfinyl radical ion from radical attack of an inter-chain disulfide peptide. The radical reactions allowed the formation of peptide sulfinyl radical ions independent of ion polarity and charge state

fewer studies have been done on peptide radical anions primarily due to limited ways of generating them in gas phase [38-40, 42]. As shown in Figure 1b, peptide sulfinyl radical anions could be generated simply by switching the ionization mode from positive to negative since the reactions are induced by radicals. The data shown in Figure 1 suggested that the atmospheric ion/radical reaction approach allowed the flexibility of forming radical ions independent of ion charge polarity.

The yield of peptide sulfinyl radical ions could be manipulated by changing the flow rate of helium in LTP. The data in Figure 2 compare the effect of helium gas flow
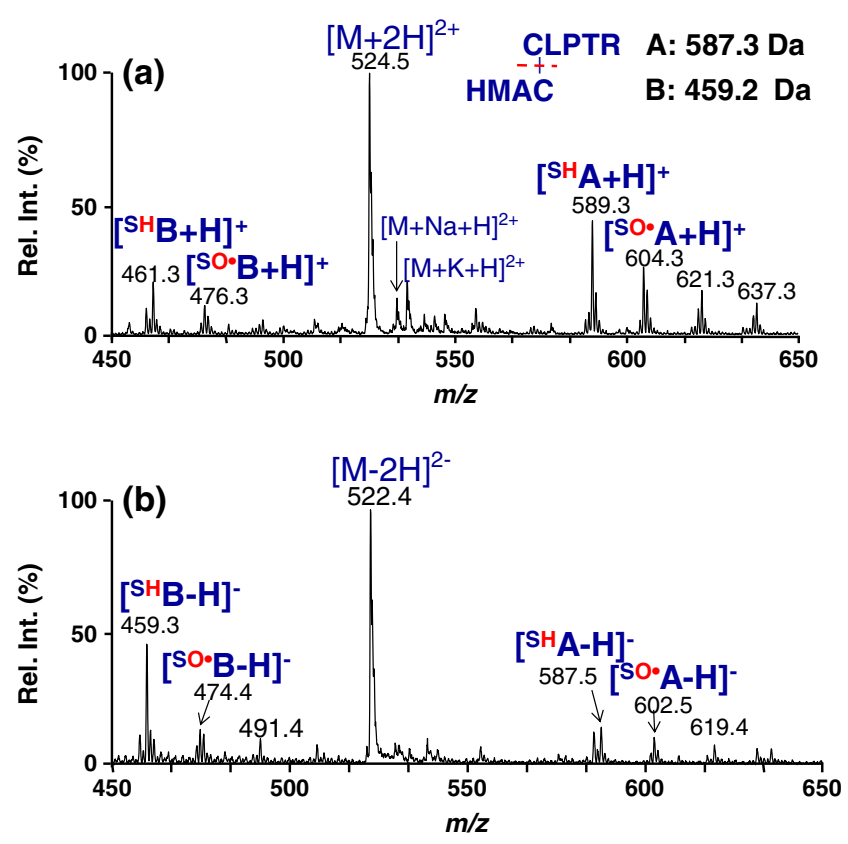

Figure 1. NanoESI mass spectra of peptide 1 when helium LTP source was also operating: (a) positive ionization mode and (b) negative ionization mode. The molecular weights of neutral chain $A$ and $B$ due to homolytic cleavage of the disulfide bond are shown in the inset of Figure 1a

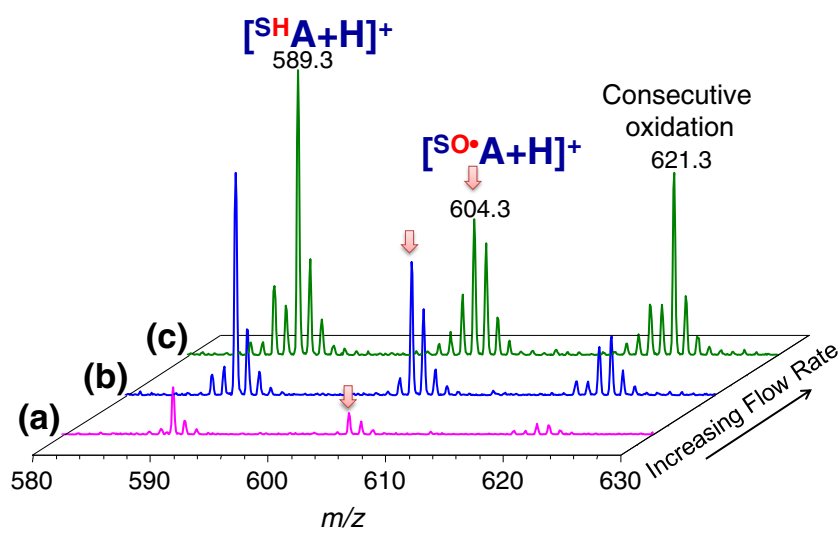

Figure 2. Expanded view for chain A region derived from nanoESI of Peptide $\mathbf{1}$ when the helium LTP source was operated with increased helium flow rates: (a) $60 \mathrm{~mL} / \mathrm{min}$; (b) $90 \mathrm{~mL} / \mathrm{min}$; (c) $110 \mathrm{~mL} / \mathrm{min}$

rates on the formation of sulfinyl radical ions for the A chain of peptide 1. Clearly, higher intensity of sulfinyl radical ions were formed with a higher helium flow rate, presumably due to higher number densities of radicals produced from more intense plasma [60]. However, consecutive oxidation of peptide side chain or reactions of the sulfinyl radical ions became more competitive and the overall yield or purity of the sulfinyl radical ions could be adversely affected [59], as shown in Figure 2c. Therefore, it was preferred to keep a moderate yield with moderate helium flow rate so that both intensity and purity of sulfinyl radical could be guaranteed. Under the optimized conditions, the relative intensity of sulfinyl radical ions was about $30 \%$ relative to the remaining parent peptide ions.

\section{Radical Attack of Free Cysteine Residue}

An alternative way of forming peptide sulfinyl radical ions is to directly oxidize peptides containing a single cysteine residue from helium LTP. The reaction spectrum of peptide 11 (sequence: CLPTR), equivalent to chain $\mathrm{A}$ of peptide $\mathbf{1}$, is used as an example (Figure 3 ). The reactions were optimized to give the best formation of sulfinyl radical at $\mathrm{m} / \mathrm{z} 604.3$ in consideration of its intensity and purity. The exact mechanism of forming the sulfinyl radical from free thiol is not clear. Based on the radical reactions of organic thiols, it can be a chain-reaction, in which thiyl radical is formed first due to hydrogen abstraction by hydroxyl radical and then quickly oxidized to sulfinyl radical [53]. Molecular oxygen and $\mathrm{NO}_{2}$ were reported to be involved in the oxidation process of thiyl radicals [6]. The advantage of using free cysteine containing peptides for the formation of peptide sulfinyl radical ions was that no additional procedure was needed to form an inter-chain disulfide peptide. However, undesirable side reactions giving rise to ions isobaric to the sulfinyl ions were typically more competitive than situations using inter-chain disulfide peptides. For instance, the $\mathrm{m} / \mathrm{z} 604.3$ 


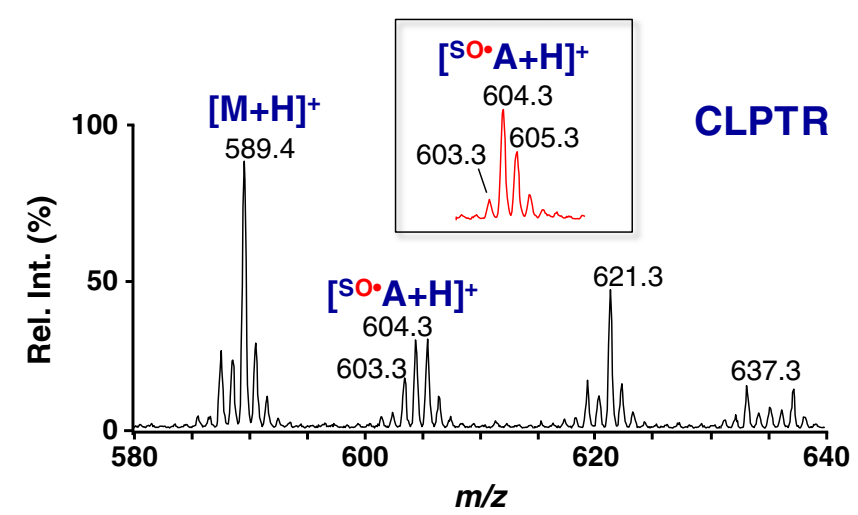

Figure 3. NanoESI mass spectrum of peptide 11(CLPTR) when the helium LTP source was also operating. The inset shows the zoomed view of sulfinyl ion region from Figure 1 (a), where peptide $\mathbf{1}$ was used to generate the same sulfinyl radical ions

ions in Figure 3 contained a significant fraction of the ${ }^{13} \mathrm{C}$ isotope from $\mathrm{m} / \mathrm{z} 603.3$ ions, which was much less when the inter-chain linked peptide was used (inset of Figure 3). CID of $\mathrm{m} / \mathrm{z} 603.3$ showed a dominant $18 \mathrm{Da}$ loss (data not shown), which was very different from CID of the sulfinyl radical ions at $\mathrm{m} / \mathrm{z}$ 604.3. The identity of this species is not clear at this moment. Under this kind of situation, yield was compromised to ensure the formation of relatively pure sulfinyl ions. In this study, peptides containing both single inter-chain disulfide bonds and free cysteines were employed to generate the peptide sulfinyl radical ions.

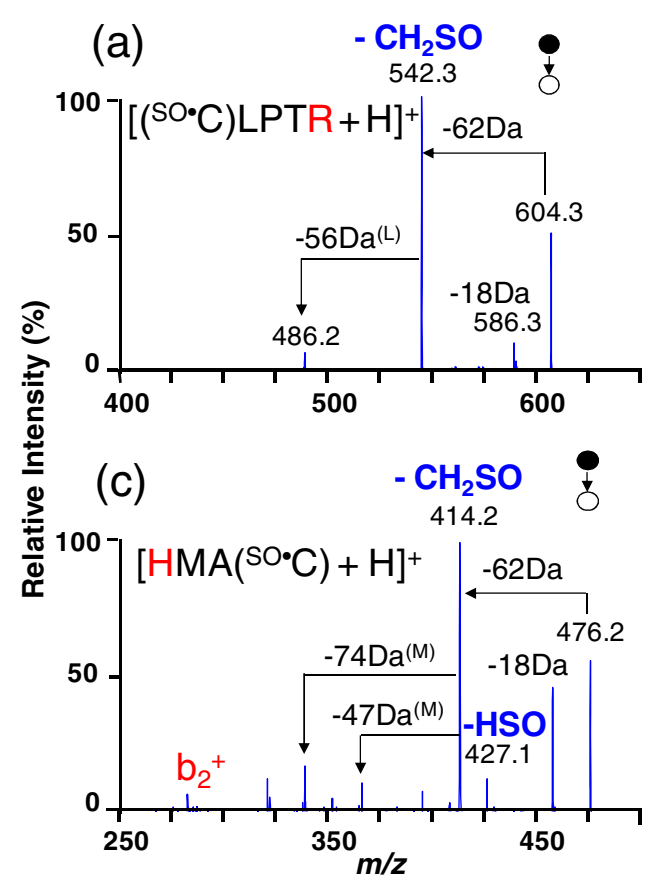

\section{Unimolecular Dissociation of Peptide Sulfinyl Radical Cations}

Collisional activation was applied to a series of peptide sulfinyl radical ions to gain insight into their gas-phase unimolecular dissociation chemistry. Given the coexistence of radical and charge, the competition of charge- versus radical-directed fragmentation pathways is of special interest. The ion trap CID spectra of four singly protonated peptide sulfinyl radical ions are selected to represent the general fragmentation behavior (Figure 4). In the first three cases, each peptide contains one basic amino acid residue, Arg, Lys, and His, respectively. Loss of 62 Da was the most favorable channel. Accurate mass measurement of this loss (61.9822 Da) corresponded to an elemental composition of $\mathrm{CH}_{2} \mathrm{SO}$ (calculated exact mass: $61.9826 \mathrm{Da}$ ). This phenomenon was observed before in $\mathrm{MS}^{3} \mathrm{CID}$ of $[\mathrm{M}+\mathrm{nH}+\mathrm{OH}]^{\mathrm{n}+}$ ions derived from intra-chain disulfide peptides [58]. The $62 \mathrm{Da}$ loss was proposed to be radical driven, resulting from a homolytic cleavage between the $\alpha$ - and $\beta$-carbons on the sulfinyl radical side chain as shown in Scheme 2. Note that this loss gives rise to glycyl radical at the original location of cysteine, which is an important radical species in enzyme chemistry [2]. Other channels such as losses of 17, 18, and $49 \mathrm{Da}$ were also observed, corresponding to $\mathrm{OH}$ or $\mathrm{NH}_{3}$, $\mathrm{H}_{2} \mathrm{O}$, and $\mathrm{HSO}$, respectively. A small degree of side chain losses following the $62 \mathrm{Da}$ loss were present as well. The possible pathways for side chain loss ions have been extensively studied for hydrogen deficient radical peptide ions and therefore are not discussed in detail herein [26, 35, $62,63]$. The sulfinyl peptide radical ions were also subjected

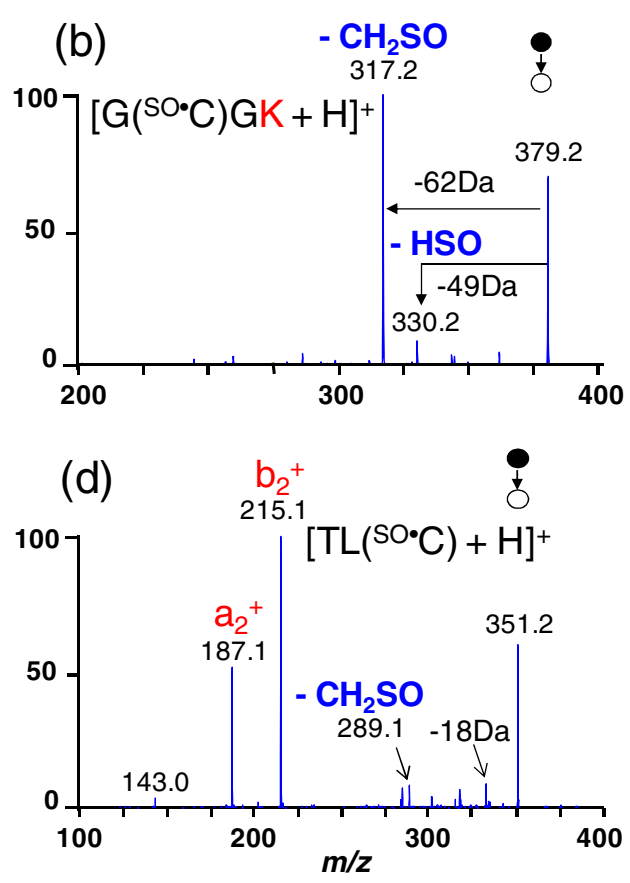

Figure 4. Ion trap CID of sulfinyl radical peptide ions: (a) $\left[\left({ }^{\mathrm{SO}}{ }^{\bullet} \mathrm{C}\right) \mathrm{LPTR}+\mathrm{H}\right]^{+}$; (b) $\left[\mathrm{G}\left({ }^{\mathrm{SO}}{ }^{\bullet} \mathrm{C}\right) \mathrm{GK}+\mathrm{H}\right]^{+}$; (c) $\left[\mathrm{HMA}\left({ }^{\mathrm{SO}} \mathrm{C}\right)+\mathrm{H}\right]^{+}$; and (d) $\left[\mathrm{TL}\left({ }^{\mathrm{SO}}{ }^{\circ} \mathrm{C}\right)+\mathrm{H}\right]^{+}$ 


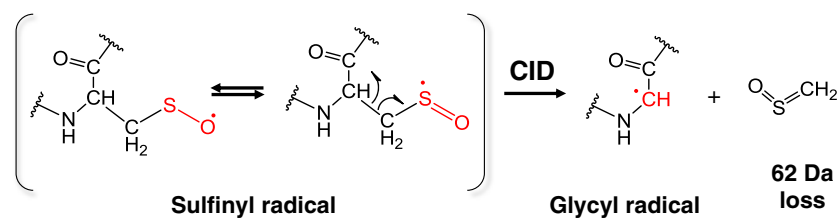

Scheme 2. Proposed pathway for the loss of 62 Da from CID of peptide sulfinyl radical ions

to beam-type CID and very similar fragmentation patterns to that of ion trap CID were observed (data not shown). However, the slightly different activation conditions (i.e., higher activation energies and shorter activation time for beam-type CID, compared with ion trap CID, did bring differences in the spectra. For example, higher intensities of 49 Da loss and sequential fragmentation were observed in beam-type CID in many cases.

The fragmentation pathway for peptides not containing any basic amino acid residue is quite different from the peptide sulfinyl radical cations containing basic amino acid residue(s). The $\mathrm{MS}^{2}$ ion trap CID data of $\left[\mathrm{TL}\left({ }^{\mathrm{SO}}{ }^{\cdot} \mathrm{C}\right)+\mathrm{H}\right]{ }^{+}$is shown as an example in Figure 4d. The 62 Da loss turns out to be very minor, whereas charge directed peptide backbone fragmentation (forming $b_{2}$ and $a_{2}$ ions) is more abundant in the spectrum. It is unclear at this point if the activation barrier for the radical-directed $62 \mathrm{Da}$ loss is affected by charge or not. However, the amide bond cleavages are facilitated by protons as being clearly depicted by the "mobile proton" theory [64, 65]. Basic amino acid residues $(\mathrm{R}, \mathrm{K}$, and $\mathrm{H})$, which sequester protons in various degrees, are known to elevate activation energies for peptide amide bond cleavages $[64,66]$. It is understandable, therefore, that the amide bond cleavages are less competitive to the radicaldirected loss in peptide sulfinyl radical ions having basic amino acid residues ( $R, K$, and $H)$. This trend was consistently observed for over 20 singly protonated peptide sulfinyl radical ions. Similar phenomenon was observed for CID of arginine containing tripeptide radical cations [6668]. Theoretical calculations by Zhao et al. showed that the energy barriers for radical migration were lowered by 5 $10 \mathrm{kcal} / \mathrm{mol}$ due to localization of charge on arginine sidechain, while the charge-directed dissociation barriers were increased significantly [67]. The major CID products of singly protonated sulfinyl radical peptides with at least one basic amino acid residue are summarized in Tables S-1 (supplemental material). Table S-2 summarizes CID of singly protonated species without basic amino acid residue.

\section{Charge State Effect}

The method of utilizing AP radical reactions also allowed facile formation of peptide sulfinyl radical ions with different charge states given that the multiple charge states could be observed for the intact peptide ions. This capability enhanced further investigation of the effect of ion charge states on radical- versus charge-directed fragmentation. The

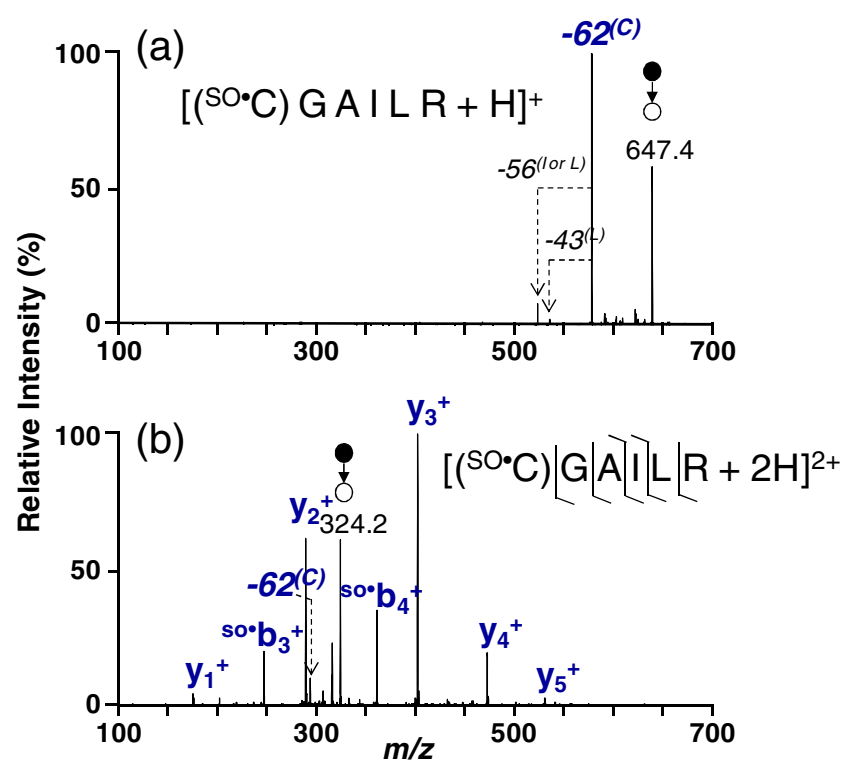

Figure 5. $\mathrm{MS}^{2}$ ion trap CID of (a) singly protonated $(\mathrm{m} / \mathrm{z}$ $647.4)$ and (b) doubly protonated $(\mathrm{m} / \mathrm{z}$ 324.2) peptide sulfinyl radical cations having a sequence of $\left({ }^{\left.\mathrm{SO}^{\circ} \mathrm{C}\right) \text { GAILR }}\right.$

data in Figure 5 shows an example of CID of singly versus doubly protonated peptide sulfinyl radical ions having a sequence of $\left({ }^{\mathrm{SO}} \mathrm{C}\right) \mathrm{GAILR}$. The extent of parent ion dissociation was kept at similar degree for comparison. Clearly, the fragmentation patterns were drastically different for $1+$ and $2+$ charge states. For the singly charged species (Figure 5a), radical-directed 62 Da loss was the most abundant fragment leading to the formation of glycyl radical

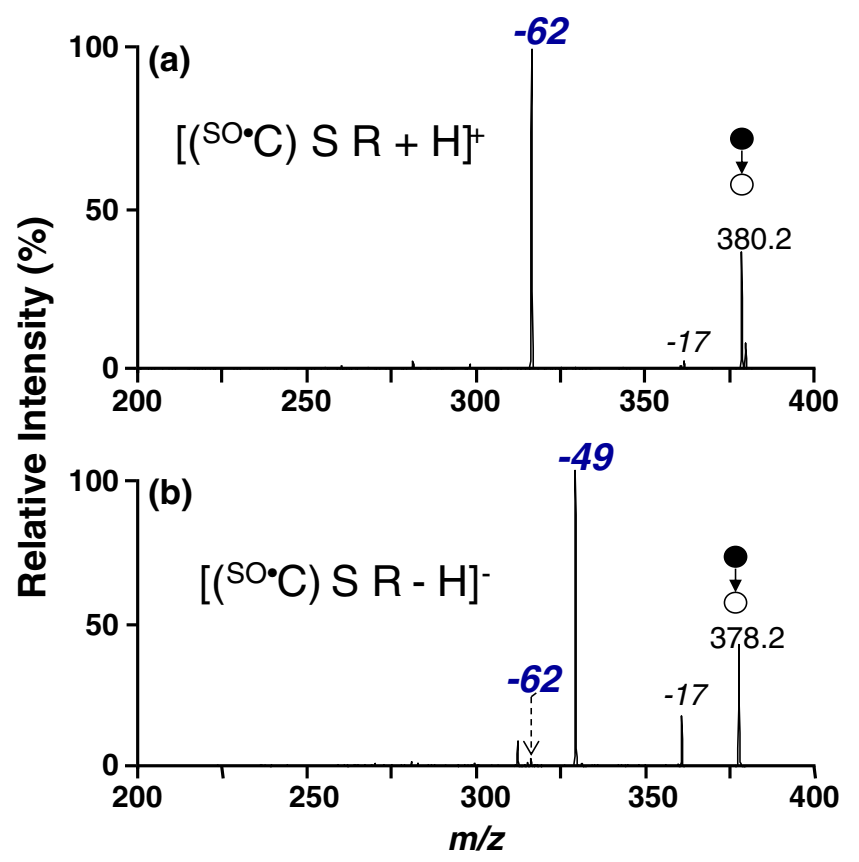

Figure 6. $\mathrm{MS}^{2}$ ion trap CID of (a) singly protonated $(\mathrm{m} / \mathrm{z}$ 380.2) and (b) singly deprotonated $(\mathrm{m} / \mathrm{z}$ 378.2) peptide sulfinyl radical ions with a same sequence of $\left({ }^{\left.\mathrm{SO}^{\circ} \mathrm{C}\right) \mathrm{SR}}\right.$ 
ions. Sequential side-chain losses from the thus formed glycyl radical ions, such as loss of $43 \mathrm{Da}$ from leucine and loss of $56 \mathrm{Da}$ from either leucine or isoleucine [62, 63], were observed as minor fragmentation channels. In the CID of doubly protonated ions (Figure 5b), the loss of $62 \mathrm{Da}$ was largely suppressed, while abundant $b$ and $y$ ions were observed. The distinct fragmentation behavior suggested that charge state (number of mobile protons) did affect the competition for radical versus charge directed fragmentation pathways. Similar to the argument made for basic amino acid residue effect, the availability of mobile protons in higher charge states effectively lowered the activation barrier for amide bond cleavages and resulted in forming abundant $b$ and $y$ ions. The observation of $y_{n}(n=1-5),{ }^{\mathrm{SO} \cdot} b_{3}^{+}$, and ${ }^{\mathrm{SO}} b_{4}{ }^{+}$(superscript "SO •" indicates the retention of sulfinyl radical on the fragments) in Figure $5 \mathrm{~b}$ demonstrated that the sulfinyl radical was retained on the original cysteine side-chain within the backbone fragments. The activation energy for peptide amide bond cleavage was reported to be within 25 to $40 \mathrm{kcal} / \mathrm{mol}$ range [69]. Therefore, it could be inferred that the activation energy of the radical directed $62 \mathrm{Da}$ loss was in comparable range to that of amide bond cleavage. Small sulfinyl radical ion systems are currently under investigation to provide a clearer picture on sulfinyl radical ion structures and energetics.

More examples of charge state effect are summarized in Table S-3. A consistent trend of suppressed 62 Da loss and increased backbone fragmentation was observed for higher charge states where mobile protons were available. Hess et al. studied the fragmentation of singly, doubly, and triply charged hydrogen deficient peptide radical cations formed via infrared multiphoton dissociation (IRMPD) and electron induced dissociation (EID). They also indicated that backbone fragmentations were highly dependent on the charge states [37].

\section{Charge Polarity Effect}

The charge polarity was found to play an important role in the unimolecular fragmentation of sulfinyl radical ions. A comparison of collisional activation of peptide sulfinyl radical cations and anions sharing the same sequence (CSR) is shown in Figure 6. For the singly protonated species (Figure 6a), loss of 62 Da was dominant as expected. However, the spectrum changed dramatically by only switching from positive mode to negative mode. The sulfinyl radical anion gave very little loss of $62 \mathrm{Da}$ but abundant loss of $49 \mathrm{Da}$. Accurate measurement confirmed that it was the loss of HSO. One possible pathway accounting for the loss of HSO might be due to a $\mathrm{C}-\mathrm{S}$ cleavage accompanied by an $\alpha$-carbon hydrogen abstraction leading to the formation of dehydroalanine at the initial cysteine site. The different behavior of the protonated versus deprotonated peptide radical ions might be explained by the stability of product ions formed in different charge polarities. The loss of $62 \mathrm{Da}$ leads to the formation of a glycyl radical. It has been suggested that peptide glycyl radical anion is less stable compared to glycyl radical cation due to the lack of stabilization from the captodative effect $[27,70]$. On the other hand, the formation of dehydroalanine from $49 \mathrm{Da}$ loss gives rise to a stable even-electron structure for anions. The main fragmentation channels for another five sulfinyl radical anions are summarized in Table S-4. The suppressed loss of 62 Da was consistently observed. In some cases loss of 93 Da was also observed. $\mathrm{MS}^{3}$ CID of the $49 \mathrm{Da}$ loss showed a dominant 44 Da loss (Figure S-1, supplemental material), suggesting that the 93 Da loss was mainly due to sequential fragmentation.

\section{Conclusions}

Radical attack to either an inter-chain disulfide bond or a free cysteine thiol group within a peptide was enabled inside an AP reactor in front of the inlet of a mass spectrometer. The AP radical reactions allowed a facile means of forming a new type of site-specific peptide radical ion species, sulfinyl radical ions, in both positive and negative ion modes and in various ion charge states. Low energy collisional activation of peptide sulfinyl radical cations revealed that proton mobility strongly affected the competition of radicaldirected side-chain losses against charge-directed backbone fragmentation. For systems with reduced proton mobility (singly protonated ions containing basic amino acid residues), radical initiated $62 \mathrm{Da}$ loss $\left(\mathrm{CH}_{2} \mathrm{SO}\right)$ dominated, likely due to the elevated activation barrier for proton facilitated backbone fragmentation. However, for systems with mobile protons, $b$ and $y$ ions from charge directed backbone fragmentation were prevalent. Loss of $62 \mathrm{Da}$ led to the formation of glycyl radical at the initial cysteine residue, which would be convenient in generating hydrogen deficient peptide radical species with known initial radical site location. Charge polarity was also found to play an important role in the dissociation behavior of peptide sulfinyl radical ions. In negative ion mode, a major loss of $49 \mathrm{Da}$ (HSO) instead of $62 \mathrm{Da}$ was observed, which might be due to the stability issue of final product. Future studies will focus on reactivity of sulfinyl radicals toward compounds containing unsaturated functional groups, disulfide bond, and sulfhydryl group, which are known to be vulnerable under radical attack.

\section{Acknowledgments}

The authors acknowledge support for this research Purdue Research Fund. The authors also thank Professor R. G. Cooks for the use of LTQ Orbitrap for accurate mass measurements.

\section{References}

1. Stubbe, J., van der Donk, W.A.: Protein radicals in enzyme catalysis. Chem. Rev. 98, 705-762 (1998)

2. Logan, D.T., Andersson, J., Sjoberg, B.M., Nordlund, P.: A glycyl radical site in the crystal structure of a class III ribonucleotide reductase. Science 283, 1499-1504 (1999) 
3. Bollinger, J.M., Edmondson, D.E., Huynh, B.H., Filley, J., Norton, J.R., Stubbe, J.: Mechanism of assembly of the tyrosyl radical-dinuclear iron cluster cofactor of ribonucleotide reductase. Science 253, 292-298 (1991)

4. Sivaraja, M., Goodin, D.B., Smith, M., Hoffman, B.M.: Identification by ENDOR of Trp191 as the Free-Radical Site in Cytochrome $c$ Peroxidase Compound ES. Science 245, 738-740 (1989)

5. Becker, A., Kabsch, W.: X-ray structure of pyruvate formate-lyase in complex with pyruvate and CoA-how the enzyme uses the Cys-418 thiyl radical for pyruvate cleavage. J. Biol. Chem. 277, 40036-40042 (2002)

6. Davies, M.J.: The oxidative environment and protein damage. Biochim. Biophys. Acta Protein Proteomics 1703, 93-109 (2005)

7. Dean, R.T., Fu, S.L., Stocker, R., Davies, M.J.: Biochemistry and pathology of radical-mediated protein oxidation. Biochem. J. 324, 1-18 (1997)

8. Stubbe, J.: Radicals with a controlled lifestyle. Chem. Commun. 2511$2513(2003)$

9. Halliwell, B., Gutteridge, J.M.C.: Free Radicals in Biology and Medicine, 4th edn. Oxford University Press Inc., New York (2007)

10. Maleknia, S.D., Downard, K.: Radical approaches to probe protein structure, folding, and interactions by mass spectrometry. Mass Spectrom. Rev. 20, 388-401 (2001)

11. Schoneich, C., Sharov, V.S.: Mass Spectrometry of Protein Modifications by Reactive Oxygen and Nitrogen Species. Free Radic. Biol. Med. 41, 1507-1520 (2006)

12. Xu, G.H., Chance, M.R.: Hydroxyl radical-mediated modification of proteins as probes for structural proteomics. Chem. Rev. 107, 3514$3543(2007)$

13. Stirk, K.M., Kiminkinen, L.K.M., Kenttämaa, H.I.: Ion Molecule Reactions of Distonic Radical Cations. Chem. Rev. 92, 1649-1665 (1992)

14. Moore, B.N., Blanksby, S.J., Julian, R.R.: Ion-molecule reactions reveal facile radical migration in peptides. Chem. Commun. 5015-5017 (2009)

15. Osburn, S., Steill, J.D., Oomens, J., O'Hair, R.A.J., van Stipdonk, M., Ryzhov, V.: Structure and Reactivity of the Cysteine Methyl Ester Radical Cation. Chem. Eur. J. 17, 873-879 (2011)

16. Aiken, A.C., DeCarlo, P.F., Jimenez, J.L.: Elemental analysis of organic species with electron ionization high-resolution mass spectrometry. Anal. Chem. 79, 8350-8358 (2007)

17. Gunawardena, H.P., He, M., Chrisman, P.A., Pitteri, S.J., Hogan, J.M., Hodges, B.D.M., McLuckey, S.A.: Electron transfer versus proton transfer in gas-phase ion/ion reactions of polyprotonated peptides. $J$. Am. Chem. Soc. 127, 12627-12639 (2005)

18. Syka, J.E.P., Coon, J.J., Schroeder, M.J., Shabanowitz, J., Hunt, D.F.: Peptide and protein sequence analysis by electron transfer dissociation mass spectrometry. Proc. Natl. Acad. Sci. U. S. A. 101, 9528-9533 (2004)

19. Zubarev, R.A., Horn, D.M., Fridriksson, E.K., Kelleher, N.L., Kruger, N.A., Lewis, M.A., Carpenter, B.K., McLafferty, F.W.: Electron capture dissociation for structural characterization of multiply charged protein cations. Anal. Chem. 72, 563-573 (2000)

20. Zubarev, R.A., Kelleher, N.L., McLafferty, F.W.: Electron capture dissociation of multiply charged protein cations. A nonergodic process. J. Am. Chem. Soc. 120, 3265-3266 (1998)

21. Tureček, F., Chen, X.H., Hao, C.T.: Where does the electron go? Electron distribution and reactivity of peptide cation radicals formed by electron transfer in the gas phase. J. Am. Chem. Soc. 130, 8818-8833 (2008)

22. Cui, W., Hu, Y., Lifshitz, C.: Time resolved photo dissociation of small peptideions - combining laser desorptionwith ion trap/reflectron TOF mass spectromerty. Eur. Phys. J. D. 20, 565-571 (2002)

23. Becker, C.H., Wu, K.J.: On the Photoionization of Large Molecules. $J$. Am. Soc. Mass Spectrom. 6, 883-888 (1995)

24. Chu, I.K., Laskin, J.: Review Formation of peptide radical ions through dissociative electron transfer in ternary metal-ligand-peptide complexes. Eur. J. Mass Spectrom. 17, 543-556 (2011)

25. Chu, I.K., Rodriguez, C.F., Rodriguez, F., Hopkinson, A.C., Siu, K.W.M.: Formation of molecular radical cations of enkephalin derivatives via collision-induced dissociation of electrospray-generated copper (II) complex ions of amines and peptides. J. Am. Soc. Mass Spectrom. 12, 1114-1119 (2001)
26. Laskin, J., Yang, Z.B., Ng, C.M.D., Chu, I.K.: Fragmentation of $\alpha$ Radical Cations of Arginine-Containing Peptides. J. Am. Soc. Mass Spectrom. 21, 511-521 (2010)

27. Osburn, S., Berden, G., Oomens, J., O'Hair, R.A.J., Ryzhov, V.: Structure and Reactivity of the $N$-Acetyl-Cysteine Radical Cation and Anion: Does Radical Migration Occur? J. Am. Soc. Mass Spectrom. 22, 1794-1803 (2011)

28. Ryzhov, V., Lam, A.K.Y., O'Hair, R.A.J.: Gas-Phase Fragmentation of Long-Lived Cysteine Radical Cations Formed Via NO Loss from Protonated S-Nitrosocysteine. J. Am. Soc. Mass Spectrom. 20, 985-995 (2009)

29. Wee, S., Mortimer, A., Moran, D., Wright, A., Barlow, C.K., O'Hair, R.A.J., Radom, L., Easton, C.J.: Gas-phase regiocontrolled generation of charged amino acid and peptide radicals Chem. Commun. 4233-4235 (2006)

30. Masterson, D.S., Yin, H.Y., Chacon, A., Hachey, D.L., Norris, J.L., Porter, N.A.: Lysine peroxycarbamates: Free radical-promoted peptide cleavage. J. Am. Chem. Soc. 126, 720-721 (2004)

31. Lee, M., Kang, M., Moon, B., Oh, H.B.: Gas-phase peptide sequencing by TEMPO-mediated radical generation. Analyst 134, 1706-1712 (2009)

32. Lee, M., Lee, Y., Kang, M., Park, H., Seong, Y., Sung, B.J., Moon, B., Oh, H.B.: Disulfide bond cleavage in TEMPO-free radical initiated peptide sequencing mass spectrometry. J. Mass Spectrom. 46, 830-839 (2011)

33. Hodyss, R., Cox, H.A., Beauchamp, J.L.: Bioconjugates for tunable peptide fragmentation: free radical initiated peptide sequencing (FRIPS). J. Am. Chem. Soc. 127, 12436-12437 (2005)

34. Ly, T., Julian, R.R.: Tracking Radical Migration in Large Hydrogen Deficient Peptides with Covalent Labels: Facile Movement does not Equal Indiscriminate Fragmentation. J. Am. Soc. Mass Spectrom. 20, 1148-1158 (2009)

35. Sun, Q.Y., Nelson, H., Ly, T., Stoltz, B.M., Julian, R.R.: Side chain chemistry mediates backbone fragmentation in hydrogen deficient peptide radicals. J. Proteome Res. 8, 958-966 (2009)

36. Ly, T., Yin, S., Loo, J.A., Julian, R.R.: Electron-induced dissociation of protonated peptides yields backbone fragmentation consistent with a hydrogen-deficient radical. Rapid Commun. Mass Spectrom. 23, 20992101 (2009)

37. Kalli, A., Hess, S.: Fragmentation of singly, doubly, and triply charged hydrogen deficient peptide radical cations in infrared multiphoton dissociation and electron induced dissociation. J. Am. Soc. Mass Spectrom. 23, 244-263 (2012)

38. Kjeldsen, F., Silivra, O.A., Ivonin, I.A., Haselmann, K.F., Gorshkov, M., Zubarev, R.A.: C-alpha-C backbone fragmentation dominates in electron detachment dissociation of gas-phase polypeptide polyanions. Chem. Eur. J. 11, 1803-1812 (2005)

39. Larraillet, V., Antoine, R., Dugourd, P., Lemoine, J.: Activated-electron photodetachment dissociation for the structural characterization of protein polyanions. Anal. Chem. 81, 8410-8416 (2009)

40. Lam, C.N.W., Chu, I.K.: Formation of anionic peptide radicals in vacuo. J. Am. Soc. Mass Spectrom. 17, 1249-1257 (2006)

41. Laskin, J., Yang, Z.B., Lam, C., Chu, I.K.: Charge-remote fragmentation of odd-electron peptide ions. Anal. Chem. 79, 6607-6614 (2007)

42. Moore, B., Sun, Q.Y., Hsu, J.C., Lee, A.H., Yoo, G.C., Ly, T., Julian, R.R.: Dissociation chemistry of hydrogen-deficient radical peptide anions. J. Am. Soc. Mass Spectrom. 23, 460-468 (2012)

43. Torreggiani, A., Barata-Vallejo, S., Chatgilialoglu, C.: Combined Raman and IR spectroscopic study on the radical-based modifications of methionine. Anal. Bioanal. Chem. 401, 1231-1239 (2011)

44. Sinha, R.K., Maitre, P., Piccirillo, S., Chiavarino, B., Crestoni, M.E., Fornarini, S.: Cysteine radical cation: a distonic structure probed by gas phase IR spectroscopy. Phys. Chem. Chem. Phys. 12, 9794-9800 (2010)

45. Steill, J., Zhao, J.F., Siu, C.K., Ke, Y.Y., Verkerk, U.H., Oomens, J., Dunbar, R.C., Hopkinson, A.C., Siu, K.W.M.: Structure of the observable histidine radical cation in the Gas phase: A captodative alpha-radical Ion. Angew. Chem. Int. Ed. 47, 9666-9668 (2008)

46. Tureček, F., Yao, C.X., Fung, Y.M.E., Hayakawa, S., Hashimoto, M., Matsubara, H.: Histidine-containing radicals in the Gas phase. J. Phys. Chem. B 113, 7347-7366 (2009)

47. Zhao, J., Siu, K.W.M., Hopkinson, A.C.: The cysteine radical cation: structures and fragmentation pathways. Phys. Chem. Chem. Phys. 10, 281-288 (2008) 
48. Hioe, J., Savasci, G., Brand, H., Zipse, H.: The stability of C-alpha peptide radicals: Why glycyl radical enzymes? Chem. Eur. J. 17, 37813789 (2011)

49. Chu, I.K., Zhao, J., Xu, M., Siu, S.O., Hopkinson, A.C., Siu, K.W.M.: Are the radical centers in peptide radical cations mobile? The generation, tautomerism, and dissociation of isomeric $\alpha$-carbon-centered triglycine radical cations in the gas phase. J. Am. Chem. Soc. 130, 7862-7872 (2008)

50. Lam, A.K.Y., Ryzhov, V., O'Hair, R.A.J.: Mobile protons versus mobile radicals: Gas-phase unimolecular chemistry of radical cations of cysteine-containing peptides. J. Am. Soc. Mass Spectrom. 21, 1296$1312(2010)$

51. Rodriquez, C.F., Cunje, A., Shoeib, T., Chu, I.K., Hopkinson, A.C., Siu, K.W.M.: Proton migration and tautomerism in protonated triglycine. J. Am. Chem. Soc. 123, 3006-3012 (2001)

52. Schurath, U., Weber, M., Becker, K.H.: Electronic-Spectrum and Structure of HSO Radical. J. Chem. Phys. 67, 110-119 (1977)

53. Tyndall, G.S., Ravishankara, A.R.: Atmospheric oxidation of reduced sulfur species. Int. J. Chem. Kinet. 23, 483-527 (1991)

54. Chatgilialoglu, C.: Sulfinyl Radicals. In: Patai, S., Rappoport, Z., Stirling, C. (eds.) Sulphones and Sulphoxides (1988), p. 1081. John Wiley and Sons, Ltd, UK (2006)

55. Zhang, W.H., Wong, K.K., Magliozzo, R.S., Kozarich, J.W.: Inactivation of pyruvate formate-lyase by dioxygen: Defining the mechanistic interplay of glycine 734 and cysteine 419 by rapid freeze-quench EPR. Biochemistry 40, 4123-4130 (2001)

56. Reddy, S.G., Wong, K.K., Parast, C.V., Peisach, J., Magliozzo, R.S., Kozarich, J.W.: Dioxygen inactivation of pyruvate formate-lyase: EPR evidence for the formation of protein-based sulfinyl and peroxyl radicals. Biochemistry 37, 558-563 (1998)

57. Gauld, J.W., Eriksson, L.A.: Oxidative degradation of pyruvate formate-lyase. J. Am. Chem. Soc. 122, 2035-2040 (2000)

58. Ma, X.X., Love, C.B., Zhang, X.R., Xia, Y.: Gas-phase fragmentation of $[\mathrm{M}+\mathrm{nH}+\mathrm{OH}]^{\mathrm{n}+}$ ions formed from peptides containing intra-molecular disulfide bonds. J. Am. Soc. Mass Spectrom. 22, 922-930 (2011)

59. Xia, Y., Cooks, R.G.: Plasma induced oxidative cleavage of disulfide bonds in polypeptides during nanoelectrospray ionization. Anal. Chem. 82, 2856-2864 (2010)

60. Chan, G.C.Y., Shelley, J.T., Jackson, A.U., Wiley, J.S., Engelhard, C., Cooks, R.G., Hieftje, G.M.: Spectroscopic plasma diagnostics on a low- temperature plasma probe for ambient mass spectrometry. J. Anal. At. Spectrom. 26, 1434-1444 (2011)

61. Nwankire, C.E., Law, V.J., Nindrayog, A., Twomey, B., Niemi, K., Milosavljevic, V., Graham, W.G., Dowling, D.P.: Electrical, thermal, and optical diagnostics of an atmospheric plasma Jet system. Plasma Chem. Plasma Process. 30, 537-552 (2010)

62. Wee, S., O'Hair, R.A.J., McFadyen, W.D.: Side-chain radical losses from radical cations allows distinction of leucine and isoleucine residues in the isomeric peptides Gly-XXX-Arg. Rapid Commun. Mass Spectrom. 16, 884-890 (2002)

63. Chu, I.K., Siu, S.O., Lam, C.N.W., Chan, J.C.Y., Rodriquez, C.F.: Formation of molecular radical cations of aliphatic tripeptides from their complexes with $\mathrm{Cu}-\mathrm{II}(12-\mathrm{crown}-4)$. Rapid Commun. Mass Spectrom. 18, 1798-1802 (2004)

64. Dongré, A.R., Jones, J.L., Somogyi, À., Wysocki, V.H.: Influence of peptide composition, gas-phase basicity, and chemical modification on fragmentation efficiency: Evidence for the mobile proton model. $J$. Am. Chem. Soc. 118, 8365-8374 (1996)

65. Wysocki, V.H., Tsaprailis, G., Smith, L.L., Breci, L.A.: Special feature: Commentary - Mobile and localized protons: A framework for understanding peptide dissociation. J. Mass Spectrom. 35, 1399-1406 (2000)

66. Xu, M.J., Song, T., Quan, Q.A., Hao, Q.A., Fang, D.C., Siu, C.K., Chu, I.K.: Effect of the N-terminal basic residue on facile $\mathrm{C}-\alpha-\mathrm{C}$ bond cleavages of aromatic-containing peptide radical cations. Phys. Chem. Chem. Phys. 13, 5888-5896 (2011)

67. Zhao, J.F., Song, T., Xu, M.J., Quan, Q., Siu, K.W.M., Hopkinson, A.C., Chu, I.K.: Intramolecular hydrogen atom migration along the backbone of cationic and neutral radical tripeptides and subsequent radical-induced dissociations. Phys. Chem. Chem. Phys. 14, 8723-8731 (2012)

68. Song, T., Ng, D.C.M., Quan, Q.A., Siu, C.K., Chu, I.K.: ArginineFacilitated $\alpha$ - and $\pi$-Radical migrations in glycylarginyltryptophan radical cations. Chem. Asian. J. 6, 888-898 (2011)

69. Lioe, H., O'Hair, R.A.J.: A novel salt bridge mechanism highlights the need for nonmobile proton conditions to promote disulfide bond cleavage in protonated peptides under low-energy collisional activation. J. Am. Soc. Mass Spectrom. 18, 1109-1123 (2007)

70. Yu, D., Rauk, A., Armstrong, D.A.: Radicals and ions of Glycine: An ab initio study of the structures and Gas-phase thermochemistry. J. Am. Chem. Soc. 117, 1789-1796 (1995) 